\title{
Can we understand citizen science?
}

\section{Bruce V. Lewenstein}

Abstract

Keywords
Citizen science is one of the most dramatic developments in science communication in the last generation. But analyses of citizen science, of what it means for science and especially for science communication, have just begun to appear. Articles in this first of two special issues of JCOM address three intertwined concerns in this emerging field: The motivation of citizen science participants, the relationship of citizen science with education, and the implications of participation for creation of democratic engagement in science-linked issues. Ultimately these articles contribute to answering the core question: What does citizen science mean?

Participation and science governance, Citizen science, Science communication: theory and models

Perhaps the most dramatic development in science communication in the last generation is the rise of citizen science. At the same time that science has become more automated and more specialized, it has also become more personal and more engaging. Researchers from astronomy to environmental monitoring to ornithology to oceanography and many other fields have used the power of intelligent, engaged nonscientists to capture, catalog, and analyze data. Communication - of research methods, of data, of results, of discussions - is fundamental to citizen science.

Citizen science serves multiple needs, both in research and in education. It provides, for example, opportunities for gathering rich data across a much wider geographic range than traditional scientific teams, while also drawing on the unique image-processing capabilities of human brains. It presents new modes for delivering educational information while also offering engagement and inquiry opportunities of the kind advocated by learning specialists.

Looking at citizen science, many significant questions emerge for scholars seeking to understand the place of citizen science in the broad ecosystem of science itself, especially questions linked to public communication of science. What kind of "public understanding" is produced by participation in scientific research? What is the relationship of participation with ideas of public engagement in science? These questions lead, in turn, to broader questions about science, democracy, and expertise. What kind of "citizenship" does citizen science produce, and what is the relationship of that citizenship with authority in policy debates and science-based decisions about management of natural resources? Who gets to be "a citizen" what kinds of social or economic factors shape participation? The list can go on. 
For all the talk of "deficit vs. dialogue" or "the shift from public understanding to public engagement," some analysts have suggested that little has been accomplished [Stilgoe, Lock and Wilsdon, 2014]. But the rapid growth of citizen science presents many examples where the challenges of democratization, the needs of science education, and the affordances of science communication have come together. Citizen scientists are learning science at the same time they are challenging scientific orthodoxies and making claims on the governance of science.

Until recently, the literature on citizen science has been scattered, appearing in science education journals, environmental sciences journals, conservation journals, public communication of science journals, and here in JCOM [Delfanti, 2010; Riesch, Potter and Davies, 2013]. Much of it exists under other labels, like "peer to peer" science, participatory science, community science, community based research, public participation in research, crowdsourced science, and so on. One article in this issue refers to "Internet-based participatory surveillance." The diversity of labels means that few practitioners or scholars realize how broad the field is.

But in the last two years, a transformation has occurred. Citizen science has appeared in Nature [Anon., 2015] and in Science [Bonney et al., 2014]. New citizen science associations and meetings have begun in Europe, the United States, and Australia. A new journal, Citizen Science: Theory and Practice, has been launched. A movement that can trace its origins back over a hundred years, and more recently has dramatically expanded through the use of the Internet and related technologies, is now a fundamental part of scientific practice.

We at JCOM are part of that explosion. A year ago, when we proposed this special issue, we wondered if enough good articles would appear. In the event, we were inundated, with nearly 40 submissions. This issue of JCOM contains the first of two sets of articles to emerge from those submissions, with a second issue planned for April.

The rush of new work poses challenges both practical (recruiting reviewers) and conceptual (what are the boundaries of citizen science?). We thank the many reviewers and especially the JCOM staff for their help managing the practical issues. At the conceptual level, we saw several overarching issues:

- What is the relationship between citizen science and public engagement? Public engagement itself has complex meanings, from "educational engagement" to "democratic participation" (http:/ / www.informalscience.org/research/wiki/Public-Engagement). Some people treat citizen science as contributing to or being based in primarily one or the other. Others claim that citizen science is precisely the route by which one kind of engagement can lead to the other. What does the evidence show?

- What is the role of communication in citizen science? Many scholars have pointed to the essential role of communication in producing reliable knowledge: without sharing of information and conclusions, research projects remain untested and not part of the knowledge collectively judged as stable and useful [Garvey, 1979; Ziman, 1968]. In citizen science, participants must communicate their work (whether observations or analysis or anything else) 
to a project hub, where it can be combined with other work. Simultaneously, many projects communicate educational information to participants, both as a step in training and as a reward for participation itself. How does this communication compare with more traditional science projects?

- What does citizen science mean? The basic contours of citizen science projects are becoming clear and various directories and portals now collate the hundreds or thousands of projects operating worldwide. Many resources provide best practices and other support for creating projects. But we don't understand yet the implications of labeling citizen science as "science." Is citizen science just a new method? Or does it somehow change the way we define and understand what science is? How do nonscientists understand their role in the scientific process? What motivates them to engage in voluntary work for which they (usually) receive no formal recognition? What do they learn from their participation in citizen science?

Some issues of importance for the practice of citizen science, such as best practices for recruitment or data management, are beyond the scope of JCOM. Our goal is to help identify issues emerging from the complex communication that citizen science entails. The articles in this issue primarily address three intertwined concerns: The motivation of citizen science participants, the relationship of citizen science with education, and the implications of participation for creation of democratic engagement in science-linked issues.

Among the most important issues in citizen science is understanding motivation: Why do people participate? What keeps them coming back? What are the implications of those motivations for education, for democratic participation, for understanding what "engagement" means to different audiences? Susan Dickerson-Lange and her colleagues, for example, showed that simply asking people to contribute data (in their case, to a study on snow cover in the Pacific Northwest region of North America) didn't actually produce sufficient data. But forming a collaboration with a school, so that participation achieved both educational and scientific goals, was much more successful.

C. G. Silva and colleagues also highlight the value of integrating citizen science projects with educational goals. The EU-funded Cell Spotting project engages participants in cancer research, using the large number of participants to analyse images of cancer cells. Evaluating the project in Portugal and Spain, where it was implemented in secondary schools, both students and teachers pointed to the importance of contributing to science as being critical to getting students engaged in a way that the usual school curriculum - motivated by the need to pass exams - does not.

Although many citizen science projects draw on primary or secondary school students as participants, fewer operate at the college level. Andrea Lucky and colleagues used two projects that do use college students to develop rigorous assessment tools for finding out what citizen scientists actually learn. Their work highlights the importance of moving beyond simple descriptive reports about citizen science, focusing instead on well-designed analyses of participant outcomes.

Anne Land-Zandstra and her colleagues give another example of careful methodology in an article that also addresses motivation and learning. Using the 
example of a long-running Dutch Great Influenza Survey, the authors explored the differences between participants with previous experience in citizen science and those new to the project. Their data confirms - with much greater methodological clarity and rigor - the impressions of many project leaders that citizen science succeeds when it is real science. Running projects solely for the purpose of education does not produce the engagement that leads to long term commitment and participation that actually leads to learning.

One kind of learning that citizen science offers is not about science, but about citizenship. Dick Kasperowski's exploration of Swedish mass experiments on the annual European Researchers" Night explores different meanings of "scientific citizenship" - ranging from creating data to inform policy through participation in the negotiations over the subsequent policy decisions. He points to the intersection of citizen science and scientific citizenship with ideas like "responsible research and innovation," another emerging development in the governance of science.

Similarly, Elizabeth Hoover's exploration of the impact of citizen science in a Native American community highlights precisely the intersection of educational and democratic goals. Even as the community agreed to contribute its own bodily fluids to a study of pollution, the participants had to negotiate issues of trust with broader political bodies that had long been suspect in the community. A citizen science project highlights how science and politics are intimately intertwined.

Finally, Sascha Dickel and Martina Franzen's exploration of the "problem of extension" (deciding who gets to count as an expert) provides a theoretical analysis of the essential tension of citizen science: how can the principles of democracy be aligned with the principles of expertise? Dickel and Franzen argue that the possibilities enabled by the shift to digital forms allow us to see "ideal types" more clearly, highlighting the issues at stake in thinking about how citizen science is changing science.

Taken together, these articles contribute to the growth of a richer understanding of the place of citizen science in the broader field of public communication of science and technology - and of the difficulty of separating that field from its neighbors, science education and the practice of science itself. None of these fields can exist in isolation; each gains strength from the other.

\section{References}

Anon. (2015). 'Rise of the citizen scientist'. Nature 524 (7565), p. 265. DOI: 10.1038/524265a.

Bonney, R., Shirk, J. L., Phillips, T. B., Wiggins, A., Ballard, H. L., Miller-Rushing, A. J. and Parrish, J. K. (2014). 'Next Steps for Citizen Science'. Science 343 (6178), pp. 1436-1437. DOI: 10.1126/science.1251554.

Delfanti, A. (2010). 'Users and peers. From citizen science to P2P science'. JCOM 9 (1), E. URL: http://jcom. sissa.it/archive/09/01/Jcom0901\%282010\%29E.

Garvey, W. D. (1979). Communication: The Essence of Science. Facilitating Information Exchange among Librarians, Scientists, Engineers and Students. Oxford/New York: Pergamon Press.

Riesch, H., Potter, C. and Davies, L. (2013). 'Combining citizen science and public engagement: the Open AirLaboratories Programme'. JCOM 12 (3), pp. 1-19. URL: http://jcom.sissa.it/archive/12/3-4/JCOM1203\%282013\%29A03. 
Stilgoe, J., Lock, S. J. and Wilsdon, J. (2014). 'Why should we promote public engagement with science?' Public Understanding of Science 23 (1), pp. 4-15. DOI: 10.1177/0963662513518154.

Ziman, J. M. (1968). Public Knowledge. An Essay Concerning the Social Dimension of Science. Cambridge, U.K.: Cambridge University Press.

Author

Bruce V. Lewenstein is Professor of Science Communication and Chair of the Department of Science \& Technology Studies at Cornell University. Member of JCOM Editorial Advisory Board. E-mail: b.lewenstein@cornell.edu.

Lewenstein, B. V. (2016). ‘Can we understand citizen science?'. JCOM 15(01), E. 